\title{
Harbin: A rust belt city revival from its strategic position
}

\author{
Liou Xie $^{\mathrm{b}}$, Zhenshan Yang ${ }^{\mathrm{a}, \mathrm{c}, *}$, Jianming Cai ${ }^{\mathrm{a}}$, Zhe Cheng ${ }^{\mathrm{a}}$, Ting Wen ${ }^{\mathrm{d}}$, Tao Song ${ }^{\mathrm{a}}$ \\ a Key Lab of Regional Sustainable Development and Modelling, Institute of Geographical Sciences and Natural Resources Research, Chinese Academy of Sciences, Beijing 100101, China \\ b Center for Earth and Environmental Science, State University of New York at Plattsburgh, Plattsburgh, NY 12901, United States \\ ${ }^{c}$ Land Economy at University of Cambridge, 19 Silver Street, Cambridge CB3 9EP, UK \\ d The Administration Center of Urban-Rural Planning, Ministry of Housing E Urban-Rural Development of P.R. China, Beijing 100835, China
}

\section{A R T I C L E I N F O}

\section{Article history:}

Received 10 December 2015

Received in revised form 1 May 2016

Accepted 4 May 2016

Available online 16 May 2016

\section{Keywords:}

Rust belt city

Harbin

Revitalization

Cold city

The Belt and Road initiative

New emerging industries

\begin{abstract}
A B S T R A C T
Rust belt cities are a special but important phenomenon in the world's industrialization landscape and city development trajectory. This profile analyses the struggling process and revitalization initiatives of Harbin, which was the first city established after the liberation of China, featuring the largest land area and highest latitude among all Chinese cities. The remarkable history of urban and industrial development once made Harbin the cradle of manufacturing in China, strongly supported by national government with concentration of SOEs. The city however has been suffering during the transition to a market economy. Its transition is painfully challenged by the strong socialist legacies of SOEs. This paper emphasizes that the new initiatives of Harbin, based on local endowments, cold climate condition and geolocation, demonstrate great potential for successful revitalization. Such strategic choices provide experiences and alternatives for other rust belt cities.
\end{abstract}

(c) 2016 Elsevier Ltd. All rights reserved.

\section{Introduction}

Harbin, the Capital of Heilongjiang province, is the largest city in Northeast China. ${ }^{1}$ Among all provincial capitals in China, Harbin has the largest land area and the second largest population size, the highest latitude and the lowest average temperature. Harbin is a city with a celebrated history of urbanization and industrialization. The city was officially founded in 1898 . The early 20th century witnessed the first golden era of its modern urban development, benefiting from the construction of Trans-Manchurian (part of the Trans-Siberian) railroad systems (see Fig. 1), the opening of port cities, and the arrival of international immigrants, especially Jewish people, on the eve of WWII.

This remarkable development continued as the Northeast became a base of state-owned heavy industry of the PRC after the country was founded in 1949 (Gamsa, 2010). The Socialist elite workers enjoyed cradle-to-grave benefits with jobs guaranteed for life. But in the 1990s, market reforms forced inefficient factories to close, throwing millions of workers out into the cold (Pei \& Yang, 2008). Efforts have been made to focus on developing more efficient industries, newly

\footnotetext{
* Corresponding author at: Land Economy at University of Cambridge, 19 Silver Street, Cambridge CB3 9EP, UK.

E-mail addresses: liou.xie@plattsburgh.edu (L. Xie), yangzs@igsnrr.ac.cn (Z. Yang), caijm@igsnrr.ac.cn (J. Cai), cz125@163.com (Z. Cheng), tingwen111@126.com (T. Wen), songtao@igsnrr.ac.cn (T. Song).

1 The Northeast (Dongbei in Chinese) is a common term that refers to three provinces in the northeast part of China, consisting of Liaoning Province, Jilin Province and Heilongjiang Province (from south to north).
}

emerging industries and green industries (Li, Zhang, \& Wang, 2014). The revitalization experiences of Harbin are particularly valuable for other rust belt cities.

This profile of Harbin is also informed by its special geo-location and development history. Although its location is far from the domestic economic and political centres, such as Beijing and Shanghai, Harbin is China's major gateway city to Russia and East Asia, and a major transportation hub in the Northeast region. Russia used Harbin as the headquarters for its operation in East Asia in the early 20th century. With the opening of 16 consulates, Harbin earned the nickname of "Paris in the Orient" and established a special position in the world urban system (Harbin Local Records Compilation Committee, 1993). Today, a large number of urban, architectural and cultural heritages are the living evidence of this era.

In the 1930s, when northeast China was part of Japan's puppet Kingdom of Manchuria, Harbin was under directly control of the Japanese, whose language was taught in schools. Japanese companies, such as Mitsubishi, opened their branches there, and Japanese banks were operating in the city too (Harris, 1994; Carter, 2002). Harbin was the first liberated city of the PRC, and gained the honourable nickname of "The Eldest Son of the Republic" (Edmonds, 1996; Harbin Local Records Compilation Committee, 1993). It was soon developed into the most important industrial base of China, and took an important position in the domestic urban system.

It is important to record the development history of a city and how its advantages and disadvantages had shifted over time, to help understand what social or political forces have been in play and what the 


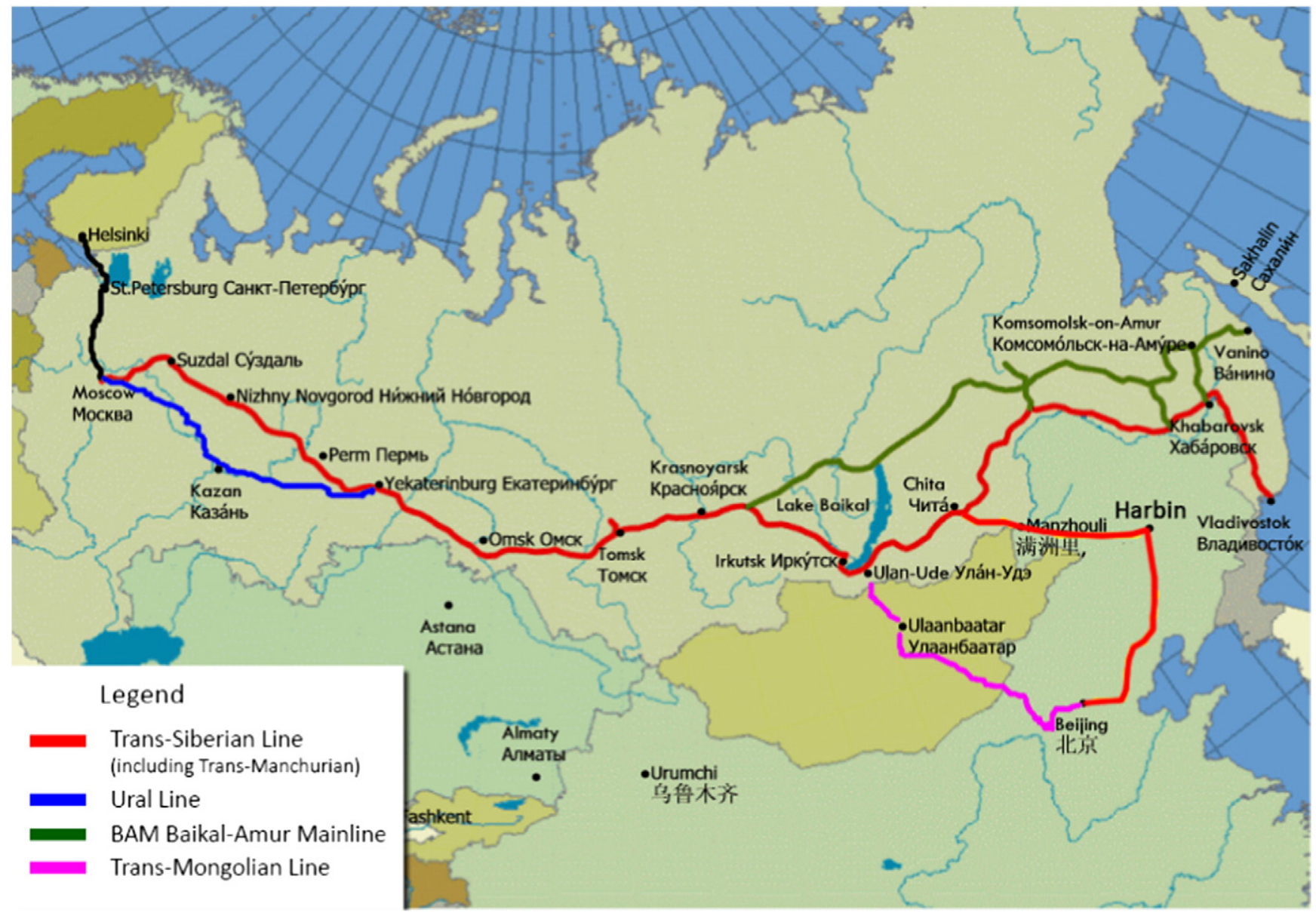

Fig. 1. Trans-Siberian railway routes.

Source: the authors (with reference to http://transsiberian.info/Transsiberianmap.gif).

impacts are (Z. Yang, Cai, Ottens, \& Sliuzas, 2013). Therefore, this article is not only interested in systematically exploring Harbin as a city, but also provides a case for urban repositioning. With industrial evolution and economic globalization, rust belt cities are prevalent in the industrial world and revitalizing them becomes a big challenge. It is quite common for rust belt cities to seek tertiary industries, such as growth coalitions promoting gentrification in Cleveland or St. Louis (Schilling \& Logan, 2008; The Economist, Jul. 11, 2015; Wilson, 2007; Wilson \& Wouters, 2003), or upgrading their manufacture with introduction of new technology, such as the biomedical research and robot engineering industry in Pittsburgh (Biggs, Feb. 2015; Greenblat, Nov. 2014; Piiparinen, Russell, \& Post, 2015; Rotstein, Oct. 2013; Thrush, Feb. 2014). However, not all such efforts are rewarded. For example, Detroiters were optimistic about revitalizing their city with amenities such as the waterfront, universities and hospitals to attract a new creative class. Companies like Quicken Loans threw themselves behind the revitalization of downtown Detroit with a vision of growing FIRE industries. After years of effort, the economy of Detroit still lacks sustaining momentum (Solomon, 2013). The paper presents an alternative approach based on the strategic geo-location and its rich resources in agriculture to explore other possibilities.

The following sections will focus on the historical development, unique strategic location, the rise and fall of SOEs, and the new industrial activities and comparative advantages in a transformed economy in Harbin. This article is based on two field trips in Harbin in November 2013 and May 2015. Interviews were conducted with key municipal government departments, including the Development and Reform Committee (DRC), the Urban and Rural Planning Bureau, the Merchants Bureau, the Tourism Bureau, and the Bureau of Land Resources, as well as four national level industrial parks in Harbin and some representative enterprises such as Nestle Group (Harbin), Harbin Aircraft Industry (Group) Co. under Aviation Industry Corporation of China (AVIC HAIG), Harbin Pharmaceutical Group Holding Co. Ltd., Nescafé, AVIC Dongan Engine (Group) Corporation Ltd., and Feilong Aviation Flight Academy, and other companies.

\section{The contested history before 1946}

Harbin was the birth place of both Jin Dynasty (1115-1234 CE) and Qing Dynasty (1636-1912 CE). In 1115 CE, the former established its Capital in Shangjing (today's Harbin). By the end of the 19th century, dozens of villages and towns had been growing at the location of today's Harbin, with a total population of 30,000 (Yue, 1993). Transportation, trading and demography started to take shape (Fig. 2).

Harbin soon developed into a thriving frontier town with significant imprints of Chinese, Japanese and Russian impacts. From 1896 to 1903, Tsarist Russia built the railroad network for its Far East area on Chinese territory and designated Harbin as the management centre, which stimulated its industrial and commercial development. Population started to grow with urban expansion. By the 1920s, Harbin had developed into a famous international trading city where there were foreign owned enterprises from over 33 countries, 16 foreign financial institutions, and 19 consulates. At its peak there were 2502 foreign owned shops. Commercial and trading connections had been established with more than 100 cities in more than 40 countries and regions (Gamsa, 2010; Yue, 1993). Even today, a large amount of Chinese Baroque style architecture, which combines the Baroque style and Chinese elements 


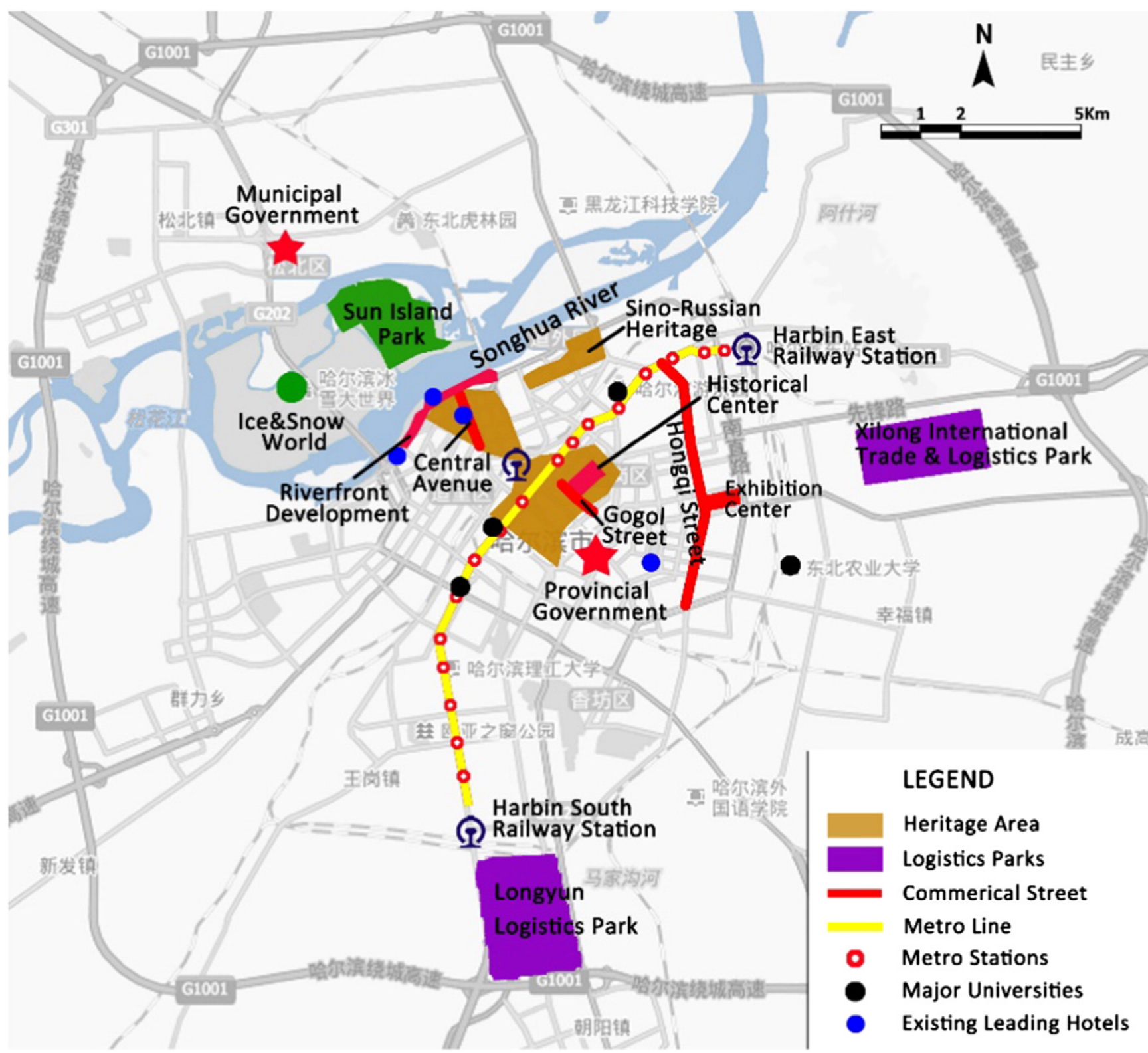

Fig. 2. Key spatial elements of Harbin.

such as crane and peony designs, is preserved in the city's ChineseRussian legacy district (see Figs. 2 \& 3).

Japan invaded Manchuria outright after the Mukden Incident in 1931, and occupied Harbin within a few hours (Matsusaka, September 2003). During the 14 years of Japanese occupation (1931-1945), Japan obtained control of railroads in Manchuria from Soviet Russia and China, and established an extensive transportation network to serve its war operation and industrial development. In 1945, the total lengths of railroads and surface road in Manchuria reached 11,479 km (compare to $22,000 \mathrm{~km}$ for the whole country in 1949) and 60,000 km (compare to $80,900 \mathrm{~km}$ for the whole country in 1949 ) respectively. Japan exploited the abundant natural resources in Manchuria, including timber, coal, iron, fishery (Wang, 2011). Japanese private capital entered all the industries in Harbin with the support of Japanese national capital, turning it into an international metropolis and the economic centre of the State of Manchuria (Yue, 1993).

Harbin was also an important base for the dissemination of Marxism, as the first Communist Party Organization in Northeast China was established there in 1923. The first congress of Party representatives in Northeast China was held here in 1927. In 1945, Harbin was regained from Japanese rule with a total population of over 700,000. However, from September 1945 to April 1946, Soviet Russia's army captured a large amount of infrastructure in the Manchurian region. On April 28, 1946, the People's Government was officially established in Harbin, marking the city as the first large city liberated (Edmonds, 1996; Harbin Local Records Compilation Committee, 1993). It was soon developed into the most important base for heavy and equipment industries of China. However, with the marketization of China's economy since 1978, Harbin suffered from significant decline as its economy was dominated by the restructuring of State-Owned Enterprises (SOEs). Recent revitalization efforts have been shifted to take the advantage of its strategic location, climate and natural resources.

\section{Strategic location and climate.}

Harbin is located at the centre of Northeast Asia (see Fig. 4), and has built a strong and complete water, land and air transportation system. Today the total area of Harbin municipality is $53,068 \mathrm{~km}^{2}$, with an 

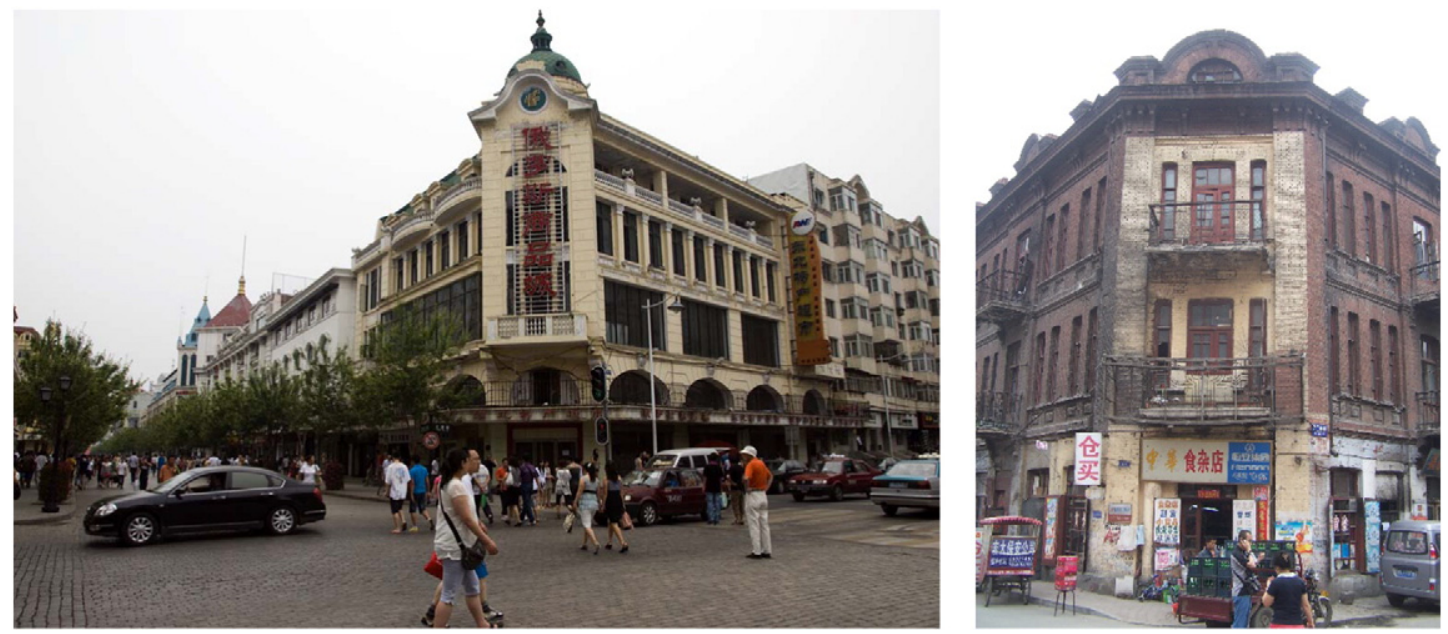

Fig. 3. Photos of Central Ave. and Chinese Baroque style architecture

urban area of 7,086 $\mathrm{km}^{2}$. It is currently administratively divided into eight districts and 10 counties (Harbin Local Records Compilation Committee, 1993). By the end of 2013, the total population was 9.95 million (Harbin Statistical Bureau, 2014b). It is also the political, economic, and cultural and transportation centre of the north part of Northeast China.

Over the land, a network of railroads and over 10 highways connect Harbin with the rest of the country, making it one of the major transportation hubs in Northeast China. The port of Harbin is one of the eight major river ports of China. Maritime routes cover Songhua River, Heilong River, Wusuli River and Nen River, and connect with some ports in Russia's Far East. Ships from Harbin can navigate out of the Strait of Tartary $(D a D a)$ and reach Japan, North Korea, South Korea, and Southeast Asia. As for air transportation, Harbin Taiping International Airport is the ideal intermediate stopping point for flights from Southeast Asia to North America (see Fig. 4). In 2014, the total passenger throughput was 12.24 million person-times, ranking 23rd in China. 25 airlines are operating 108 domestic and international flights between Harbin and 62 cities (Heilongjiang Airports Management Group, 2015).

Harbin is also the metropolis of China closest to Russia and has historically been the gateway for exchanges between these two countries. The annual Harbin International Economic and Trade Fair, which started in 1990, has been a critical event for promoting trading and economic cooperation with Russia and the Commonwealth of Independent States. This strategic location has been renewed many times for promoting national development strategies, for instance the recent "Belt and Road" Initiative which aims at promoting international communication and cooperation. Although Harbin is not directly on the Belt or the Road, it is a major land transportation node in the Northeast Asian region and adds to the overall initiative as the pivoting point for the "ChinaMongolia-Russia Economic Corridor". It has been planned by the provincial government of Heilongjiang to intensively invest in the infrastructure for connecting the corridor including railroads, roads, waterways, air transportation and communication facilities (see Fig. 4).

Harbin enjoys a temperate Continental Monsoon climate which brings distinct seasons. The summer is short and cool with an average temperature of $23^{\circ} \mathrm{C}$, while the winter is long and cold with an average temperature of $-19^{\circ} \mathrm{C}$. The average annual rainfall is $569.1 \mathrm{~mm}, 60 \%$ of which is concentrated in the summer between June and September. Winters are snowy, lasting as long as 105 days yearly. The Songhua River is frozen for about 137 days (Harbin Municipal Government, 2015). Endowed with the unique snowscape, Harbin has been recognized as the centre of snow cultural activities in China and the symbol of a winter city. The art of Ice Lanterns was originated in Harbin (see Fig. 5).

\section{The Socialist Era (1946-1978) and its legacies}

\section{1. "The eldest son of the republic": the cradle of modern industrial devel-} opment of China

In 1946, Harbin was designated by the Chinese Communist Government as a strategic area for industrial location on grounds of spatial proximity to Russia and rich natural resources. These advantages turned the city and surrounding areas into one of the most important bases for heavy industry, equipment manufacturing industry and national defence industry. During the first "Five Year" period (1953-1957), some major industrial projects assisted by the USSR were located in Harbin. Along with an administration system that prioritized production during the planned economy era, Harbin well deserved its premier status as the power house of the New China.

The development of industries in Harbin enjoyed two unprecedented opportunities. The first was the relocation of factories from the south to the north (nan chang bei qian) during the Korean War (1950-1953: Yue, 1993). A number of medium to large enterprises from Liaoning province were relocated to Harbin, including what turned out to be today's Harbin First Machinery Manufacturing Group Corporation, Songjiang Electric Machinery Factory, Longjiang Electric Works, Harbin Wire and Cable Factory, Harbin Bearing Factory, and Harbin Forestry Machinery Factory. The relocation of these well-developed enterprises, and the revitalization of historical enterprises, enabled the transition of Harbin's urban function to production, which was a major achievement of its urban industrial development (Pei \& Yang, 2008).

The second opportunity was that 13 out of 156 USSR-assisted industrial projects were located in Harbin, including what are today's Harbin Electric Machinery Factory, Harbin Boiler Company Limited, Harbin Turbine Company Limited, Dong'an Machinery Factory, Northeast Light Alloy Fabrication Plant, Harbin Measuring \& Cutting Tool Works, Harbin Electrical Measuring Instruments (Group) Co., Ltd., Harbin Electrical Carbon Factory and Harbin Insulating Materials Factory (Pei \& Yang, 2008; Yue, 1993). These projects facilitated the dramatic change of Harbin's industrial structure.

By the end of the 1950s, machinery, electricity, chemicals, building materials and lumber became the fastest growing industries. The total number of SOEs increased to 259. Its industrial output was 1.47 billion yuan, accounting for more than $50 \%$ of total GDP of the municipality, ranking No. 7 of all major cities in China. Harbin was developed into a remarkable emerging industrial city and was referred to as the "cradle of China's industry" (Li et al., 2014; Zhang, 2008). 


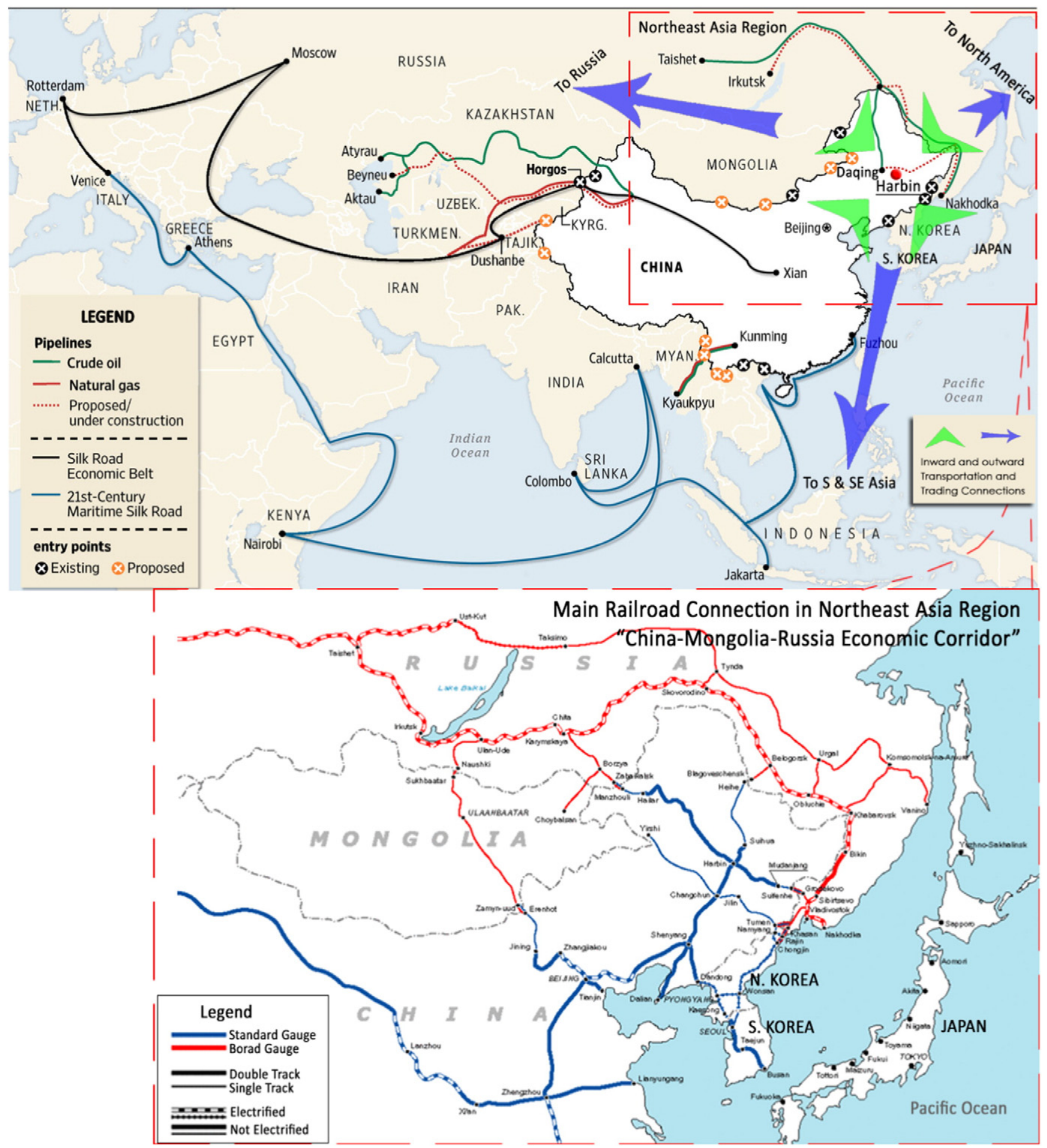

Fig. 4. Geolocation of Harbin in Northeast Asia and the Belt and Road Initiative.

Source: the authors (modified from Xiahua and the Wall Street Journal: http://www.wsj.com/articles/chinas-new-trade-routes-centerit-on-geopolitical-map-1415559290, and from Mongolia Daily Economic Update: http://www.mongoliaeconomy.com/wp-content/ uploads/2014/11/42101.gif).

\section{The economic, social and spatial legacies}

In China, the term State-owned Enterprise refers to enterprises completely owned by the state and under direct control of line ministries. Under the planned economy regime (1949-1978), SOEs followed rules established by the central government, fulfilled the production targets set by state planners and sold their products at predetermined prices (Fan \& Hope, 2013). In addition to their function as the employers, SOEs also played an important role of providing livelihood for the workers, most importantly a wide of range of social services including education, housing, health care and retirement protection. At a time when China was struggling to recover and rebuild its economy from war devastation, SOEs were the main form of both economic and social organization of the Chinese society, providing the cradle-to-grave care for a large proportion of its urban population. In addition, SOEs were the most preferred recipients of generous bank loans which were also state-owned. 


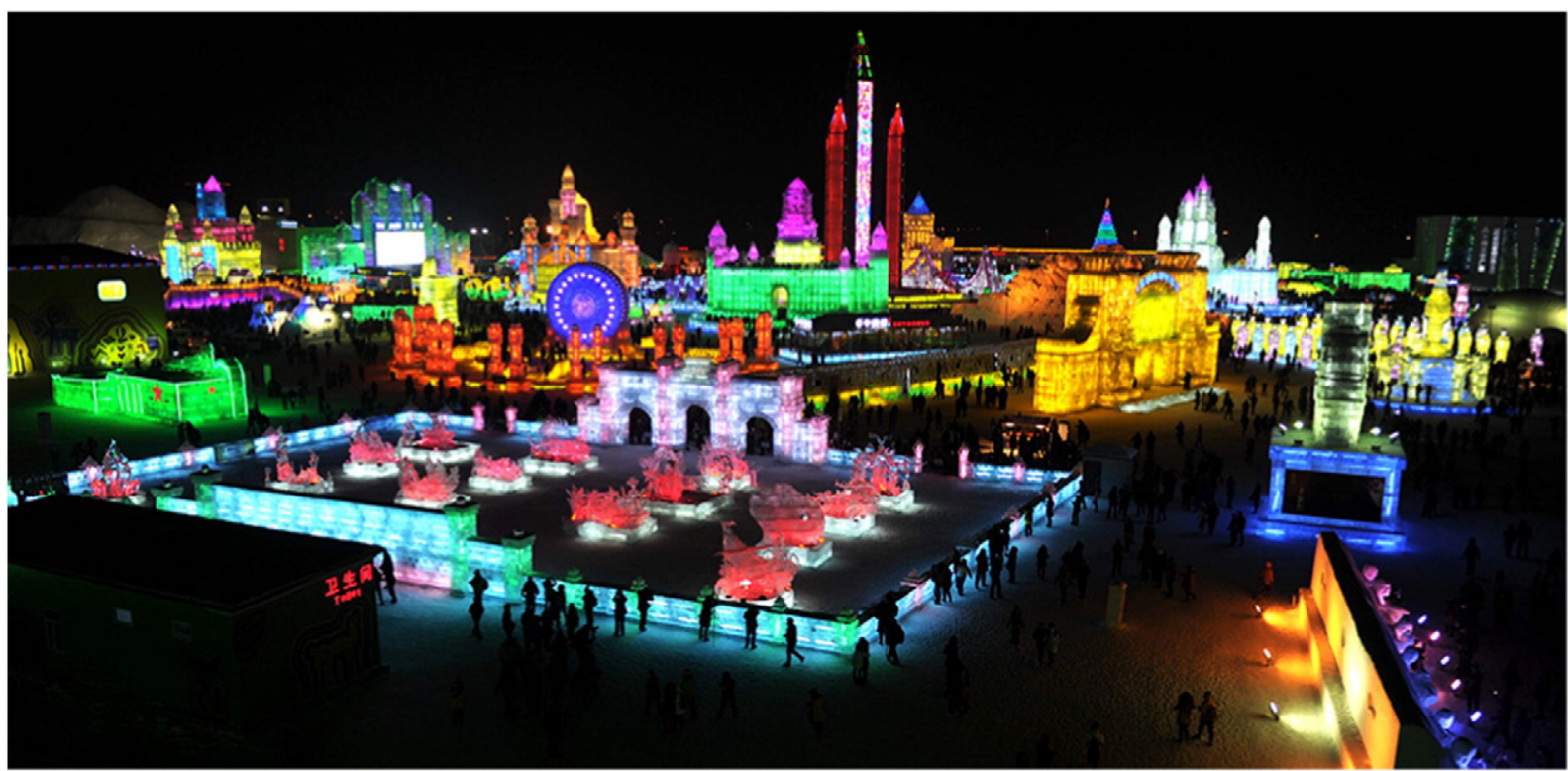

Fig. 5. Ice Lanterns and the Harbin Ice and Snow Amusement World.

Today, the spatial layout of Harbin's manufacturing industries still reflects these historical and socialist imprints. Four major industrial clusters are recognized: 1) the "Three Power Equipment" industrial district, featuring Harbin Electric Machinery Factory, Harbin Boiler Company Limited and Harbin Turbine Company Limited; 2) the Pingfang industrial district featuring aviation industry; 3 ) the Taiping industrial district focusing on Chemical industry; and 4) the Nangang industrial district characterized by higher education and R/D. Harbin plays a critical role in the country's manufacturing of power station equipment, bearings, measuring tools, magnesium alloys and national defence products.

\section{Struggles in the transition (after 1980s)}

\subsection{Struggling transitions of the economy}

The "Open and Reform" policies since 1980s have been characterized by economic marketization, privatization and economic decentralization. Budgets, production outputs and sales of SOEs are no longer planned or arranged by the central government. Bank loans become more and more difficult to obtain. Many inefficient SOEs have been closed down, merged, or sold. Harbin, whose economy was dominated by SOEs, has been facing major challenges with these transitions (see Fig. 6). For about twenty years (1978-1998), the annual growth of

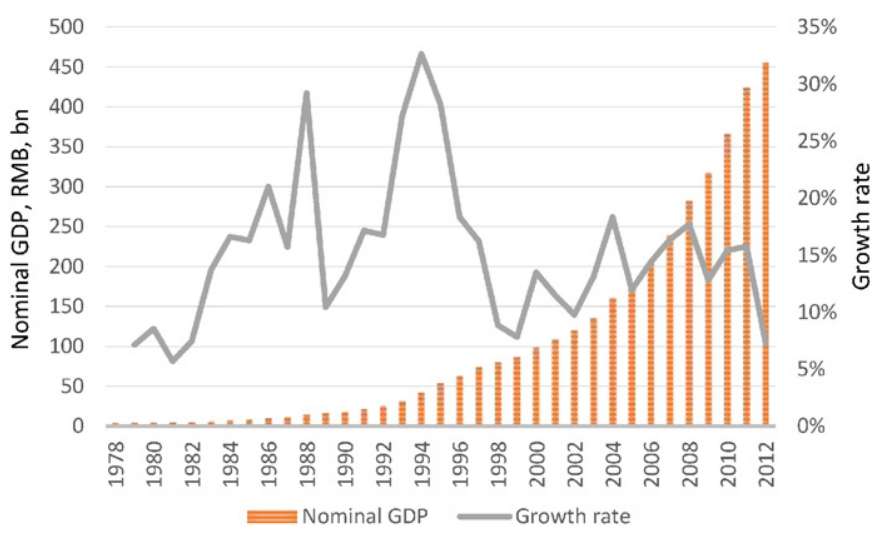

Source data: Harbin Statistical Yearbook 2013

Fig. 6. Nominal GDP and its growth in Harbin. Source data: Harbin Statistical Yearbook 2013. nominal GDP fluctuated significantly between lower than $10 \%$ and over 30\%. The fluctuation of GDP growth shows several key stages of Harbin's economy. The first is the stage (1978-1988) when the SOEs continued to enjoy their strong status formed in the planned economy period. In 1984, China took economic reform in all economic sectors and established a socialist commodity economy. In February 1988 the blueprint of the implement of market economy was issued, which called for establishing modern enterprises. These policies exert huge impacts on SOEs. In 1989, the annual growth rate for nominal GDP fell dramatically to $10 \%$. After that, Harbin had a period of fast growth (1990-1994), largely benefiting from the strength of its manufacturing capacity accumulated before such as pharmaceuticals and equipment. These strengths however were quickly lost due to the slow process of SOE reforms and fierce market competition. In 1998, a large number of SOE workers were laid off with the intention of relieving the 'burden' of the SOEs and refreshing their vitality. In 2004, with recognition of struggling transitions and the importance of heavy industries in Northeast China, the Central Government initiated the national "Revitalization of the Northeast" strategies in 2004. The municipal government of Harbin has been actively exploring for effective ways to revive its economy, too. Since then, the annual growth rate of nominal GDP fluctuated less significantly and stayed at around $12 \%$ until 2011 , but dropped to $7 \%$ in 2012 (see Fig. 6).

Affected by the global financial crisis, China's overall nominal GDP growth rate decreased to 7.7\% during 2013-2014. For the same period, Harbin's nominal GDP growth was at a lower level of $6.4 \%$, indicating a poorer economic performance related to an unsuccessful economic structuring on top of the global financial crisis (Harbin Statistical Bureau, 2014b). Taking a closer look at the Northeast China region, Harbin had an economic output value of 534 billion yuan in 2014, ranking the lowest level among the four main cities (Harbin, Shenyang, Dalian and Changchun) in the Northeast, although they shared similar levels of industrial development during the planned economy era (1949-1978).

The core of the "Revitalization of the Northeast" initiative is to help revitalize the region's industries while encouraging industrial restructuring, economic reforms and regional cooperation. However, the economies of Harbin were not restructured as expected. As shown in Fig. 7, manufacturing is still dominated by food processing and heavy industries. Food processing accounted for the highest share $(42.3 \%)$ in 2013 . The second highest was the processing industry of petroleum coking processing of nuclear fuel, accounting for $10.3 \%$. General and special equipment manufacturing accounted for $6.8 \%$. 


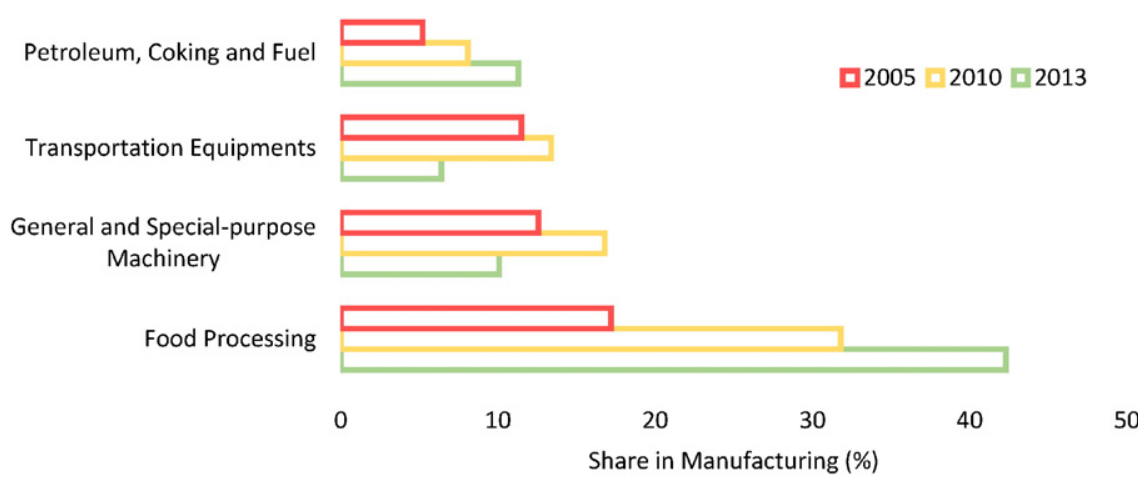

Source data: Harbin Statistical Yearbook 2006, 2011, and 2014

Fig. 7. Change of shares of key sectors in manufacturing in Harbin.

Source data: Harbin Statistical Yearbook 2006, 2011, and 2014.

Like many other rust belt cities, Harbin attempted to develop service industries to stimulate and strengthen a consumption economy. However, although the contribution of service industry to the total GDP grew from $48.6 \%$ in 2000 to $53.5 \%$ in 2013 , the total economic output of service industries was only 268.6 billion yuan in 2013, ranking 3rd in the four main cities in the Northeast China, lower than Dalian (328.1 billion yuan) and Shenyang (313.8 billion yuan), but higher than Changchun (201.2 billion yuan). Among all service industries, the financial industry was observed to have the fastest annual growth rate of $25.2 \%$ between 2008 and 2013, followed by the real estate industry with a $10.4 \%$ annual growth rate (see Fig. 8 ).

\subsection{Social struggles}

The struggles of Harbin have also been reflected on its population loss, urban poverty and high unemployment rate. The ex-workers who were laid-off by the closed, merged or streamlined SOEs have been struggling in a very difficult position, with the private industry not big enough to absorb all of them. Although the municipal and district governments offer some relief allowances and re-employment training programs, the laid-off workers find themselves sliding slowly into the urban underclass (Cho, 2013; Hurst, 2009). Official data stated

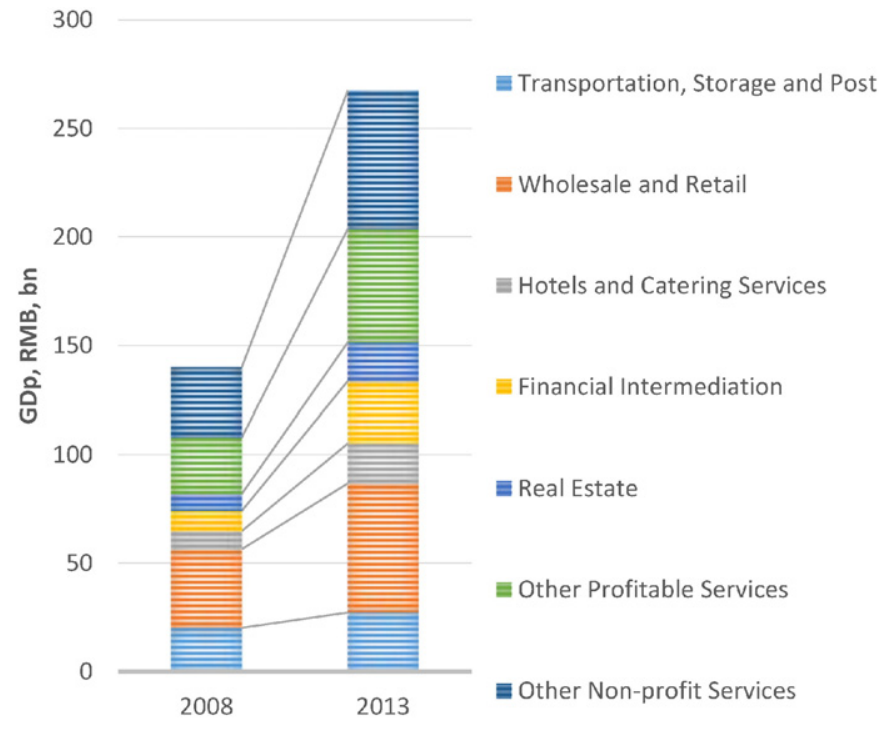

Source data: Harbin Statistical Yearbook 2009 and 2014

Fig. 8. Change of services structure in Harbin.

Source data: Harbin Statistical Yearbook 2009 and 2014. that the registered urban unemployment rate ranges between $3.2 \%$ and 4.5\% from 2000 to 2015 (Harbin Municipal Government Official Website). However, the official unemployment data in China has been criticized by social workers and researchers for underestimation. The Blue Book of China's Society 2008, published by the Chinese Academy of Sciences (2008), argued that the actual urban unemployment rate should have been $9.4 \%$, which more than doubled the official data of $4.2 \%$ and was well above the international alert line of $7 \%$. Similar problem exists for the official data for Harbin.

When the chance of finding a good job locally is slim, some look to relocate to other regions for better employment opportunities. Between 2000 and 2013, the annual growth rate of total population of Harbin remained at a low level of $0.4 \%$. Registered urban population stagnated since 2006. Out migration was observed. In 2013, the total net migration was 12,097 people for the municipality. Two of the eight urban districts had negative population growth. More challenging for Northeast China is the loss of educated talents. There are 88 post-secondary institutions in total, contributing $10 \%$ to the nation's total graduates. But a large percentage of them choose to leave the Northeast in search for jobs. By the end of 2013, the total population was 9.95 million, of which 4.74 million were urban population. According to the sixth census in 2010, the urbanization rate of Harbin was $47 \%$, which was lower than the national average (see Fig. 9).

\subsection{Lessons learned from past experiences}

The challenges faced by Harbin during the economic transition were closely associated with its SOE-dominant economy. The advantages that Harbin had enjoyed since 1949 as a key national industrial base resulted in the large number of SOEs. Although a round of major SOE reforms

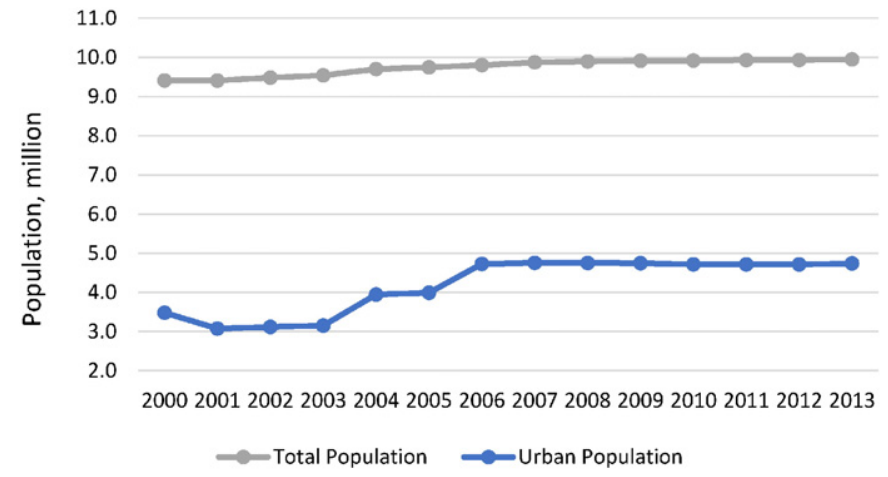

Source data: Harbin Statistical Yearbook 2014

Fig. 9. Population dynamics.

Source data: Harbin Statistical Yearbook 2014. 
happened in 2004 and successfully reduced the share of state-owned economy in total GDP, strong socialist legacies have been limiting the speed and extent of SOE reforms. Until today, SOEs still play a leading role in some industries and are strongly tied to Harbin's economic performance. Strong legacy of the state-own economy poses great challenges to the overall competitiveness of the city.

Instead of actively seeking market solutions to improve their competitiveness, the SOEs undergoing reforms tend to show a prevailing attitude of "Waiting, Depending and Requesting", which stands for "Waiting for national financial aids; depending on fiscal appropriation from governments of higher levels; and/or requesting fiscal alleviation funds". This was observed at the meeting of main SOEs in 2013 (when field work was being undertaken). There was a clear appeal of all interviewed SOEs asking for subsidies from the municipal government, vividly in contrast to the interest of the government in identifying the vitality and market potential of their business. For example, Harbin Aircraft, the leader of aero manufacturing company in Harbin, heavily relies on the order assigned by AVIC HAI, and requires further subsidies and loans, rather than technology inputs from the government. As a result, the reforms enforced on SOE, especially the large-scale ones, failed to bring economic competitiveness to them. In 2013, 210 enterprises above designated size $\mathrm{e}^{2}$ were running in the red with a loss-making percentage of $17.9 \%$. The total amount of loss amounted to 4.37 billion yuan.

The legacy of a state-owned economy has a negative impact on the establishment of new enterprises. Therefore, it was difficult to build a modern corporation system for the SOEs undergoing reforms, which results in confusion of corporate authorities and responsibilities and loss of market competitiveness. Personal opinions and administrative hierarchical procedure hinder the development of upstream and downstream industries or the formation of cooperation among enterprises. Under the legacy of SOEs and strong intervention of government in business management, some enterprises criticize that even when SOEs are restructured, the CEOs of the SOEs may not be able to have their own decisions in the company, simply because some other senior managers could reject these decisions as they have closer relationship with or were even assigned by the government (interviewed with key enterprises on Nov. 21, 2013).

The Plan of Revitalizing Northeast Region heavily relies on investment-driven programs, and paradoxically a huge amount of capital invested in traditional heavy industries (Xu \& Liu, 2016; D. Yang \& Zhao, 2015), especially on heavy industries and resources-oriented industries, rather than services sectors and information and technology industry. For instance, in 2013, the city invested 522 billion yuan on fixed assets, which almost doubled that of 2000 (Harbin Statistical Bureau, 2014a). The R/D investment by enterprises above designated scale was 5.16 billion yuan, and total investment in research, cultural and medical assets reached 27.7 billion yuan in 2013, respectively accounting for $1 \%$ and $5 \%$ of the total fixed asset investment (Harbin Statistical Bureau, 2014b). Fixed asset investment, including investment on physical assets, such as real estate infrastructure, machinery and equipment, has a large and long-term effect on production and wealth creation. However, this is a big loss for the government to rely on investment rather than exploiting new market opportunities, and such an investing structure also creates conflict in the interest of restructuring economies towards services. However, the reason could be the lack of clear and context-based strategy for the revitalization plan, as we observed.

The last decade was also the era of local governments relying on land sales and real estate development to achieve GDP growth targets, although it is widely recognized that selling land (use right) is barely a sustainable source of income (Tian, September 3, 2014). In 2014, the

\footnotetext{
2 "Enterprise above designated scale" is a statistical term used in People's Republic of China since 1996. The threshold changed a couple times. Since 2011, it refers to the industrial enterprises with an annual income from their main business of over 20 million yuan.
}

Central Government launched a national audit of the "land-transferring fees" collected by local government for the previous six years. Results showed that income from land sales accounted for as high as 35\% of local governments' fiscal revenue in 2013 (Chen, August 21, 2014). According to data collected from various pages on Harbin's Municipal Government official website, the contribution of land-transferring fees was as much as $46.2 \%$ for Harbin municipal government in 2009, which increased to 50.4\% in 2011. However, in 2012, the contribution of landtransferring fees plummeted to $11.7 \%$ and increased slightly to $17.8 \%$ in 2013. This significant decline of land sales in Harbin suggests that it has passed the market capacity for real estate construction as a result of a challenged economy and a declining urban population. The municipal government has to seek for more sustainable sources of its revenue income.

\subsection{New strategies looking forward}

Efforts have been made to explore alternative strategies for economic revitalization of Harbin. Like other Chinese cities, Harbin has been experimenting to coordinate the economic and spatial factors in the form of industrial parks to facilitate infrastructure provision and to implement industrial strategies to economically function the park.

Besides the industrial zones established during the planned economy era, Harbin has been building various types of industrial parks since the 1990s. By 2009, the total number of industrial parks in Harbin Municipality, reached 57, of which 26 parks were designated as key industrial ones with a total planned area of $880.4 \mathrm{~km}^{2}$, occupying a huge amount of land in both urban districts and rural land (Table 1). However, these industrial parks are not well coordinated spatially, nor did they form well-structured industrial clusters. For example, pharmaceutical industries are located in both Limin ETDZ and Harbin ETDZ (Nangang Zone). Such fragmentation of economic foundation goes against industrial clustering which improves innovation, productivity and competitiveness.

The above problems associated with industrial parks were not unique to Harbin. The Central Government required all cities to consolidate small and competing industrial parks since late 2000s. For Harbin, the consolidation work was carried out during 2010-2014. Main parks at present include three national level ETDZs, which are Hanan Industrial New Town, Binxi ETDZ in Bin County and Limin ETDZ in Hulan District, and one national level HTDZ which was in Nangang District but has been relocated to Songbei District and renamed as Harbin Scientific \& Technological Innovation New Town (see Fig. 10). In addition, there is the "Three Power Equipment" industrial district formed during the planned economy era, which however has been declining with the contraction of turbine and traditional engine industries. In planning, each park attempts to have a relatively clear goal of promoted industries, to take advantage of their past achievements while avoiding repetitiveness and unnecessary local competitiveness.

More importantly, Harbin's transportation plan well integrates the spatial layout of consolidated industrial parks. Three of the major industrial zones are already connected by the circular highway, facilitating a fast movement of raw materials and finished products. Public transportation, especially the subway system, has been designed and constructed to improve the quality of life for local residents, and to provide excellent transportation connections for the industrial parks (see details in Fig. 10). Currently only a small portion of the lines in the city centre is completed and in operation. The newly planned lines are intended to not only intensify downtown connections, but also reach into most of the industrial parks, including the ones not yet well served by highways and artery roads to create a highly integrated urban spatial structure.

In our survey, some key industries and measures are identified with potential in terms of past achievements, strengths and newly located firms, as shown in Fig. 11. In the traditional equipment manufacturing district in the east part of town, continuous reforms are being performed on the SOEs to help them transform from the power industries 


\section{Table 1}

Main industrial parks before consolidation, 2010.

Source: compiled by authors from data collected in the interviews.

\begin{tabular}{|c|c|c|c|}
\hline Location & $\begin{array}{l}\text { Industrial Sub-industrial parks } \\
\text { parks }\end{array}$ & Key industries & Key enterprises \\
\hline \multirow[t]{2}{*}{$\begin{array}{l}\text { South of } \\
\text { the } \\
\text { urban } \\
\text { centre }\end{array}$} & $\begin{array}{ll}\text { Hanan } & \text { Haping Site and Nangang Site of the Harbin } \\
\text { Industrial } & \text { Economic and Technological Development Zone, } \\
\text { New } & \text { Shuangcheng Industrial Park, Pingfang Industrial } \\
\text { Town } & \text { Park, Niujia Industrial Park, Harbin Mechanical } \\
& \text { and Electrical Industrial Park, Acheng Xinhua } \\
& \text { New Area, Acheng Sheli Industrial Area, } \\
& \text { Shuangcheng Zhoujia Industrial Park, Xiangfang } \\
& \text { Industrial Park }\end{array}$ & $\begin{array}{l}\text { Transportation equipment, new equipment } \\
\text { manufacturing, new material, food, } \\
\text { pharmaceutical, electronic information, } \\
\text { modern services }\end{array}$ & $\begin{array}{l}\text { Hafei Airbus Composite Manufacturing Centre } \\
\text { Ltd., Dongqing Metals Manufacturing Co., Ltd., } \\
\text { Yinghua Electric Power Equipment } \\
\text { Manufacturing Co., Ltd., FAW Automotive, } \\
\text { Guangming Cloud Media, Guoyu Financial Data } \\
\text { Center, Suning Appliance Logistics Network, Hafei } \\
\text { Motor Co., Ltd., Yihai Jiali Cereal \& Oil Foodstuff } \\
\text { Industry Co., Ltd., Coca-Cola, McCain Foods, Oishi, } \\
\text { Miqi Food }\end{array}$ \\
\hline & $\begin{array}{l}\text { Acheng Economic and } \\
\text { Technological } \\
\text { Development Zone }\end{array}$ & Metallurgy, construction materials & $\begin{array}{l}\text { Xinbeiyuan Power Station Equipment, Jiajie } \\
\text { Combustion Engineering, Jindu Huayu Power } \\
\text { Station Equipment, Xinxin Precision Metal } \\
\text { Manufacturing, Huasheng Energy Saving } \\
\text { Technology, Beitang Machinery, Beihuan } \\
\text { Machinery, Huaguang Energy Saving Facilities }\end{array}$ \\
\hline \multirow[t]{3}{*}{$\begin{array}{l}\text { North of } \\
\text { the city }\end{array}$} & $\begin{array}{l}\text { Jiangbei Technology \& } \\
\text { Innovation New Town }\end{array}$ & $\begin{array}{l}\text { Modern electronic information, biological } \\
\text { medicine, optic-mechanical integration, new } \\
\text { materials, advanced energy conservation and } \\
\text { environmental protection }\end{array}$ & $\begin{array}{l}\text { Haisibi Boats Technology Co., Ltd., Bright Ocean } \\
\text { Inter-Telecom Co., Ltd., Kyushu Electric Power } \\
\text { Co., Ltd., Sihai Numerical Control Technology } \\
\text { Stock Co., Ltd., COSLIGHT, Synjones, Tekcore, } \\
\text { Centrin Data System Ltd., Nations Data Services } \\
\text { Ltd. }\end{array}$ \\
\hline & Limin ETDZ & $\begin{array}{l}\text { Pharmaceutical manufacturing, biological } \\
\text { medicine, agro-food processing, beverage } \\
\text { processing and manufacturing, equipment } \\
\text { manufacturing, new construction materials } \\
\text { manufacturing }\end{array}$ & $\begin{array}{l}\text { Harbin Pharmaceutical Group Co. Ltd., Sanjing } \\
\text { Pharmaceutical Shareholding Co., Ltd., Medisan } \\
\text { Pharmaceutical Co., Ltd., Gloria Pharmaceuticals, } \\
\text { Zhengda Industrial Co., Ltd., China Brewing Group } \\
\text { Co., Ltd., Longdan Diary, Harbin Zhengyanghe } \\
\text { Seasoning Co., Ltd., Harbin Bearing Manufacturing } \\
\text { Co., Ltd., Harbin Electric Carbon Factory, Huayou } \\
\text { Power Equipment Manufacturing Co., Ltd. }\end{array}$ \\
\hline & $\begin{array}{l}\text { Songbei Economic } \\
\text { Development Zone }\end{array}$ & Tobacco and special equipment manufacturing & Hulan First Tractor, LOVOL \\
\hline $\begin{array}{l}\text { East of the } \\
\text { city }\end{array}$ & $\begin{array}{l}\text { Three Power Equipment } \\
\text { Industrial District }\end{array}$ & Engine, turbine, and equipment industries & $\begin{array}{l}\text { Harbin Electric Group (merger of the former } \\
\text { Harbin Electric Machinery Factory, Harbin Boiler } \\
\text { Company Limited, Harbin Turbine Company } \\
\text { Limited) }\end{array}$ \\
\hline \multirow[t]{3}{*}{$\begin{array}{l}\text { West of } \\
\text { the city }\end{array}$} & Binxi ETDZ & $\begin{array}{l}\text { General and special equipment manufacturing, } \\
\text { agro-food processing. }\end{array}$ & $\begin{array}{l}\text { Binzhou Cement Co., Ltd., Jinmailang Food, Aurora } \\
\text { Optoelectronics Co., Ltd., Binxi Cattle Industry Co., } \\
\text { Ltd., Sihai Numerical Control Technology Stock } \\
\text { Co., Ltd. }\end{array}$ \\
\hline & $\begin{array}{l}\text { Yingbin Road Site of the Harbin } \\
\text { HighTech Development Zone }\end{array}$ & $\begin{array}{l}\text { Automotive industry, food and beverage } \\
\text { processing manufacturing, medicine, high-tech } \\
\text { industry }\end{array}$ & $\begin{array}{l}\text { Harbin Hi-Tech Soybean Food Co., COSLIGHT, } \\
\text { Harbin Air Conditioning Co., Ltd., Harbin Boshi } \\
\text { Automation Co., Ltd. }\end{array}$ \\
\hline & Daoli Xinyu Industrial Park & $\begin{array}{l}\text { Construction materials, machinery industry, } \\
\text { deep processing of agricultural products }\end{array}$ & $\begin{array}{l}\text { Harbin Longfei Welding Equipment, Yaxiya } \\
\text { Electric Equipment, Yutian Steel Tube, Changpu } \\
\text { Plastic Cement Co., Ltd. }\end{array}$ \\
\hline \multirow{8}{*}{$\begin{array}{l}\text { Peri-urban } \\
\text { and } \\
\text { rural } \\
\text { area }\end{array}$} & Shuangcheng Economic & Food and beverage processing manufacturing & $\begin{array}{l}\text { Nestle, Wahaha, Yurun, Huiyuan Beverage, Want } \\
\text { Want, Qia Qia, Wandashan Dairy, Huafeng Foods }\end{array}$ \\
\hline & Shangzhi City Economic Zone & $\begin{array}{l}\text { Agro-food processing, food and beverage } \\
\text { processing, timber processing and products }\end{array}$ & $\begin{array}{l}\text { Mengniu Dairy, East Hope Group, Hanfeng } \\
\text { Evergreen Inc., TrueLove Foods, Hanfeng Slow } \\
\text { Release Fertilizer Co., Ltd. }\end{array}$ \\
\hline & Yanshou Industrial Park & Agro-food processing, textile manufacturing & $\begin{array}{l}\text { Yonghe King, Xiangqi Soy Sauce Industry Co. Ltd., } \\
\text { Wanyuan Environmental Protection Co., Ltd., } \\
\text { Wandekai New Construction Material } \\
\text { Development Co., Ltd., Order Group, Yizhi Pen Co., } \\
\text { Ltd. }\end{array}$ \\
\hline & Bayan Industrial Demonstrative Base & $\begin{array}{l}\text { Agro-food processing, timber processing and } \\
\text { products, bearing manufacturing }\end{array}$ & $\begin{array}{l}\text { Jinluo Meat Products Co., Ltd., Harbin High Tech } \\
\text { Group Co., Ltd. }\end{array}$ \\
\hline & Mulan Fengxian Park & $\begin{array}{l}\text { Agro-food processing, willow manufacturing, } \\
\text { textile manufacturing }\end{array}$ & $\begin{array}{l}\text { Harbin Hande Cattle Industry Co., Ltd., Jinqiao } \\
\text { Beer Co., Ltd., Harbin Lvhuayuan Fresh Vegetables } \\
\text { Co., Ltd., Shanghai and Harbin Biotechnology } \\
\text { Development Co., Ltd. }\end{array}$ \\
\hline & Tonghe Industrial Demonstrative Base & $\begin{array}{l}\text { Agro-food processing, timber processing and } \\
\text { products, non-metallic mineral processing, } \\
\text { medicine }\end{array}$ & $\begin{array}{l}\text { Jiulian Window Decorations Manufacture Co., } \\
\text { Ltd., Pharmaceutical Co., Ltd., HPGC, Cunming } \\
\text { Wood Industry Co., Ltd., Baijiade Cold Drink Co., } \\
\text { Ltd., Xinma Thermal Power Group }\end{array}$ \\
\hline & Fangzheng Economic Development Zone & $\begin{array}{l}\text { Quartz silica processing, Agro-food processing, } \\
\text { timber processing and products }\end{array}$ & $\begin{array}{l}\text { Tianying Tube Industry, Huadian Group, Tiandi } \\
\text { Pharmaceutical Co., Ltd., Xinglong Wood Industry } \\
\text { Co., Ltd., Shengyu Wood Industry Co., Ltd., Da } \\
\text { Chang Industry Co., Ltd., Harbin Guanqiang } \\
\text { Optoelectronic FDevice Co., Ltd. }\end{array}$ \\
\hline & Yilan Economic Development Zone & $\begin{array}{l}\text { Coal chemical industry, chemical raw materials } \\
\text { and chemicals manufacturing }\end{array}$ & $\begin{array}{l}\text { Harbin Coal Chemical Industry Co., Ltd., Zhongtai } \\
\text { Construction Group Co., Ltd. }\end{array}$ \\
\hline
\end{tabular}




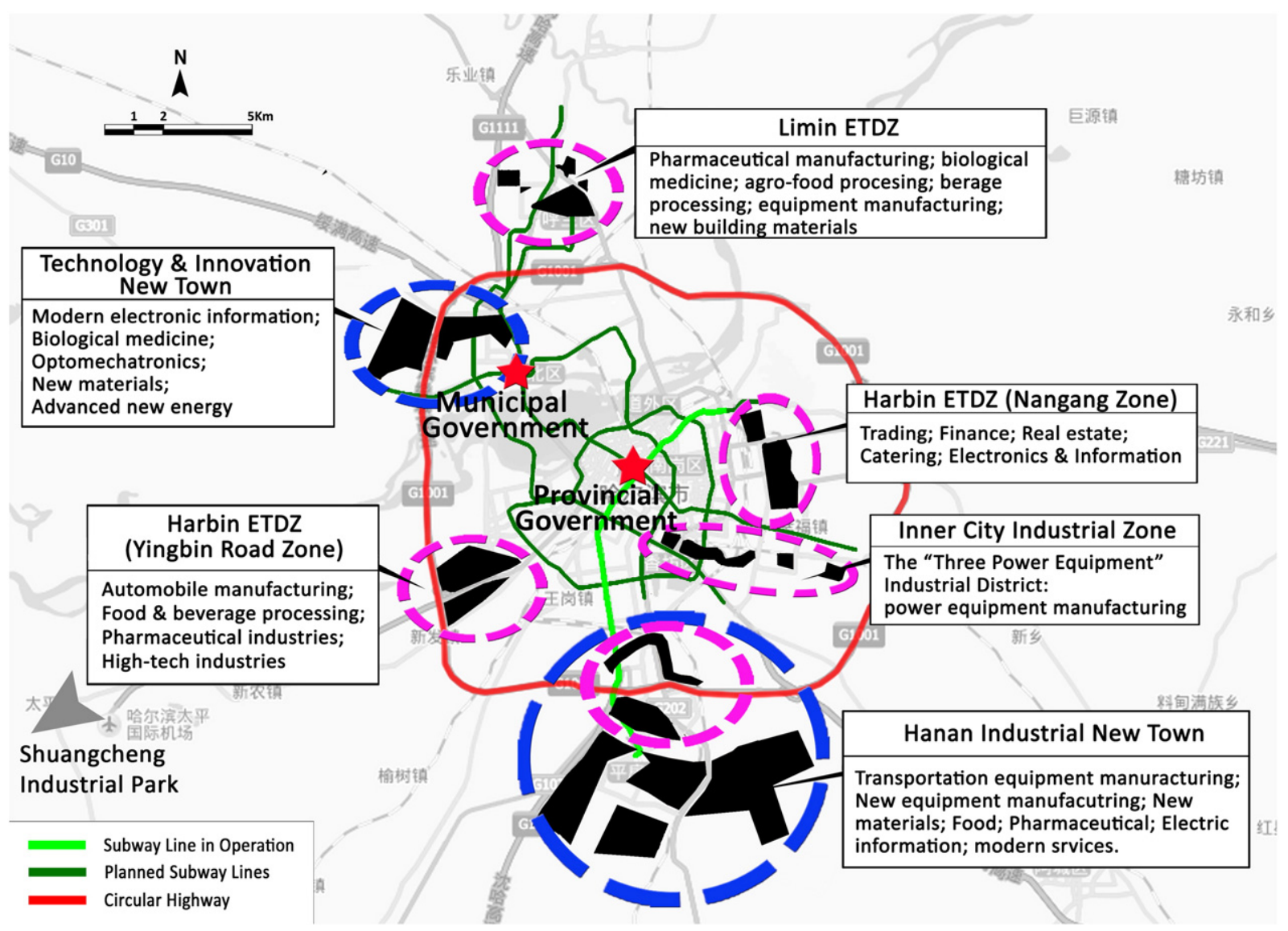

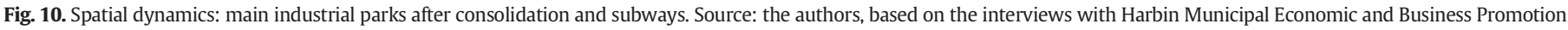

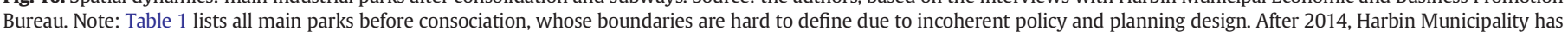

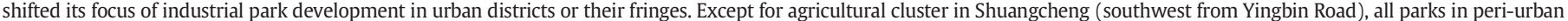

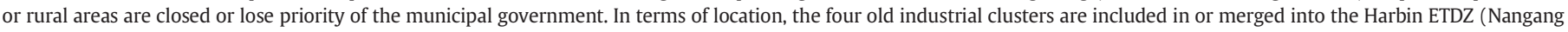

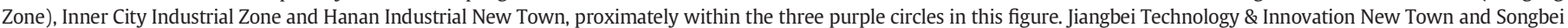

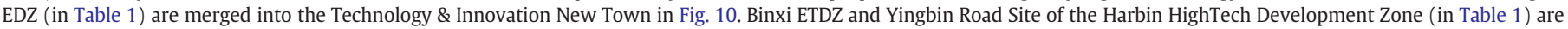
integrated into the Harbin ETDZ (Yingbin Road Zone) in Fig. 10.

to manufacturing of advanced equipment. In Hanan Industrial New Town, emphasis is being put on building China's Cloud Valley focusing on developing cloud computing and data storage. At the same time, development space is being reserved in the North Technology and Innovation Town for future expansion of back office cloud service for the industries of finance, pharmaceutical, power and etc. Hanan Industrial New Town is also the ideal location for developing the aviation cluster which is supported by composite material industry. Limin ETDZ focuses on the Pharmaceutical industrial cluster. A large green food processing and agricultural cluster is planned in Harbin ETDZ (Yingbin Road Zone), to take advantage of the surrounding rural areas. The downtown area of Harbin will emphasize on building exhibition centres and developing a commercial, financial, exhibition and tourism core.

Among others, some initiatives are positioned according to the strategic location and the natural endowment of Harbin, which has shown promising future, making Harbin quite different from other cities.

\subsubsection{Agricultural cluster}

Benefiting from its natural conditions and soil resources, agriculture plays an important role in Harbin's economy. As a major grain producing area, Harbin is a key producing base of quality soybean, quality and special maize, and pollution-free green paddy rice. Black soil with abundant organic matter, favorable environment for soybean and malt production, and rich husbandry resources are some key advantages of
Harbin. It is one of the first cities in China which brought green food production into its legal management system. There is already a sizable green food industry with extensive domestic and international marketing network. This key competiveness of Harbin for developing the agricultural cluster is summarized in Table 2.

Harbin also holds excellent research capacity as there are 26 universities, colleges and research institutes in farming, forestry, animal husbandry and fishing industries such as Northeast Agricultural University. Over 2000 scientists and technologists in agriculture bred new and quality varieties of paddy rice, maize, soybean and vegetable, and invented advanced agricultural technologies.

In order to realize the potential of agriculture cluster, Harbin has been developing the green agricultural industry rigorously. Currently, over 300 varieties of crops have obtained the national "green" or "organic" certificate. Its agricultural products are sold to over 30 countries and regions, with over 8 billion yuan of annual sales. All these efforts enable agriculture becomes a very promising industry, with the share of GDP increasing from 10.5\% in 2011 to $11.7 \%$ in 2013. Food processing industry (including food processing, food and beverage manufacturing) grew significantly to a total economic output of 809.2 billion yuan in 2013 , accounting for $42.3 \%$ of the manufacturing industry. Both its upstream and downstream industries have been showing strong performance and growth potential in Harbin.

However, there are still some areas where Harbin could improve its agricultural cluster. The ratio of economic output of agricultural product processing to agricultural industry is above 3 for most of the developed 


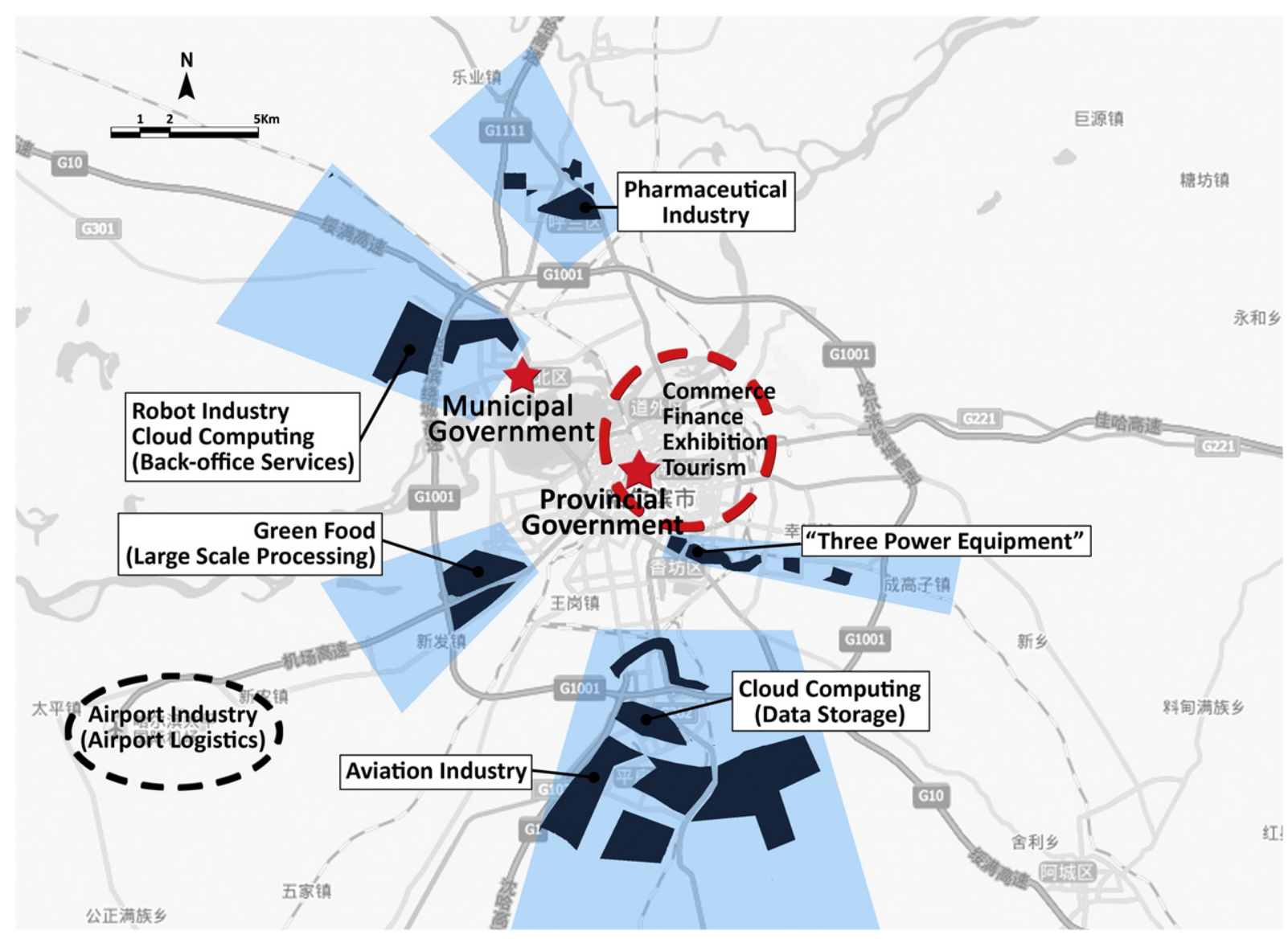

Fig. 11. New initiatives of key parks and spatial economic dynamics.

world, but 0.96 for Harbin, slightly higher than the national average of 0.8 for China. At the same time, the contribution rate of science and technology advancement to the agricultural products processing industry in Harbin is only 0.35 (interview with Harbin Agricultural Bureau in 2013). Therefore, there are great potential for improving Harbin's industrial productivity and commercialization of technology in agriculture, which should benefit significantly from the huge amount of local intellectual resources. Many enterprises operate on out-dated equipment, with limited low-level trained personnel, resulting in low technical innovation capability. Some enterprises are still producing with manual operation and indigenous methods.

\section{Table 2}

Harbin's competitiveness for green food industry.

Source: the authors.

\begin{tabular}{ll}
\hline Item & Advantages \\
\hline $\begin{array}{c}\text { Production factor } \\
\text { endowments }\end{array}$ & $\begin{array}{l}\text { One of the three black soil zones in the world, with } \\
\text { abundant organic matter } \\
\text { A main production area of soybean in China and in } \\
\text { the world } \\
\text { Top production area of malt in China } \\
\text { Abundant green animal husbandry resources } \\
\text { One of the first cities which established green food } \\
\text { management regulations } \\
\text { Enacted technical operation procedure and data } \\
\text { management approach for production, service, and } \\
\text { marketing management for green food } \\
\text { There are ten green food companies which have } \\
\text { annual sales revenue of above 100 million RMB } \\
\text { Established and improved more than 3000 green } \\
\text { food marketing network domestically and } \\
\text { internationally }\end{array}$ \\
&
\end{tabular}

\subsubsection{Aviation and low-altitude industries}

The aviation industry has a long history in Harbin. Harbin Aircraft Industry Group (AVIC HAIG) was founded in April 1952. It is the major production base of helicopters, light and general-purposed aircrafts, regional jet airplanes, aero engines, automobiles, auto engines, metallurgical equipment and spare parts, medical packaging machinery, and gas turbine generators. The company has a production capacity of $300 \mathrm{~K}$ automobiles, $650 \mathrm{~K}$ engines, 100 helicopters and airplanes, and 50 transmission systems for aero engines. As a comparison, Bombardiers delivered 73 commercial aircrafts, 199 business aircrafts and 3 amphibious crafts in 2015 (Bombardier Aerospace, 2015).

Since the 1970s, the aviation industry in Harbin has been collaborating with international companies such as Lockheed Corporation (USA), Aérospatiale (France), British Aerospace (UK), Rolls-Royce Group plc. (UK), Airbus Helicopter (France), and ZFL Luftfahrttechnik (ZF Aviation Technology, Germany). AVIC HAIG introduced patented helicopter technologies from France in the 1980s, and gradually achieved 95\% domestic technologies. Now it has started to produce parts for Boeing 787 and Airbus A350.

The aviation industry benefits from Harbin's research capacity and talent pool. There are 49 technical universities and colleges including Harbin Institute of Technology, Harbin Engineering University, and Harbin University of Science and Technology, with about $480 \mathrm{~K}$ students. There are also specialized research institute for the aviation industry such as the AVIC Aerodynamics Research Institute, and training institutes for pilots such as Feilong Aviation Flight Academy.

Hanan Industrial New Town is where Harbin's civil and general aviation industries cluster. It hosts some major civil aviation projects such as AVIO aeronautical transmission system, high precision tube axle for helicopters (Dong'an Group), AVIC Aerodynamics Research Institute, and Harbin Hafei Airbus Composite Manufacturing Centre. In 2012 , 
the Aerospace High-tech Innovation Industrial Park project was initiated, with a total investment of 1.67 billion yuan, which covers an area of $340 \mathrm{~K} \mathrm{~m}^{2}$. This project focuses on titanium alloy with a total investment of 1.35 billion yuan. Titanium alloy is an important new structural material in the aerospace industry. It is mostly used in the manufacturing of aircraft engine compressor, as well as in structural parts of rockets, missiles and high-speed aircrafts. This new project will stimulate the development of low cost but high quality new types of titanium alloy and further improve the competitiveness of Harbin's aviation industry.

The key opportunity for aviation industry is the loosening up of restrictions on low-altitude operations in China. As a result, the general aviation industry has been experiencing great opportunities for growth recently. The strategic geo-location of Harbin as the logistics node in Northeast Asia and in the recently proposed Belt and Road Initiative offers great advantages for developing a low-altitude economy with upstream and downstream industries. So far, Harbin has been focused on the upstream industries such as R\&D, equipment and parts manufacturing, assembly, maintenance services, training and operation. There is a lot of potential for developing the downstream industries in Harbin such as low-altitude tourism which takes advantages of the vast local natural and culture landscapes. As a newly emerging economy, the low-altitude economy entails a very complex and extensive industrial chain with a great amount of value. Compared with other competitive cities in China which are also promoting this newly emerging economy, Harbin enjoys the advantages of excellent human resources due. More importantly, as a new form of economy, there are fewer challenges from the economic reforms which present a better potential for success.

\subsubsection{The role of private small and medium enterprises (SME)}

Under the shadow of SOEs, SMEs used to be only a small portion of Harbin's economy. But they have been growing rapidly, contributing an increasing share of the city's economic output. By 2013, the total number of SMEs in Harbin accounted for $99.9 \%$ of all enterprises, and employed 1.17 million people, contributing to more than $68 \%$ of the tax revenue of the local governments (China Business Times, June 17, 2014).

The growth of SMEs brings with opportunities and innovates city economies. Among others, cross-border e-commerce is an important one. According to our survey in 2015, cross-border e-commerce started in 2013 in Harbin. Now there are about 20 companies specialized in trading between China and Russia. In November 2013 and June 2014, air cargo services were opened between Harbin and Yekaterinburg, Russia, and Aktobe, Kazakhstan. In 2014, the total value of parcels sent from Harbin to Russia amounted to US\$ 200 million, accounting for $30 \%$ of China-Russia parcels. Alibaba contributed significantly to this export economy between Harbin and Russia by shortening the shipping time from 1.5-2 months to 2 weeks, and by providing an online payment system that accepts both Chinese yuan and Russian ruble. Harbin also enjoys an advantage of human capital with over 6000 students majored in Russian language. A number of successful SMEs not only contribute to economic growth of Harbin, but also provide employment opportunities for the local specialized labor force.

\section{Conclusion}

Different from many other rust belt cities, Harbin's economy turns its focus back to primary industry and new forms of secondary industry and has found some new growth poles. Some efforts have been rewarded, for example the growth of agriculture, aviation and lowaltitude industry, and cross-border ecommerce. These new initiatives are based on natural endowments and strategic location, which are highly likely to be reinforced under China new program "Belt and Road" to emphasize the central role of Harbin in the international cooperation in the Northeast Asian region. If these industrial strategies work, Harbin's experiences strongly suggest that services industries are not the only way to revitalize rust belt cities. A more practical and creative approach should be encouraged based on local resources, conditions and opportunities. Effects of all these efforts on economic revitalization and population gain still need further examination over time.

The experience of Harbin also shows major challenges for rust belt cities in a revitalization process. In particular, this process is beset with reforming of SOEs in addition to high industrial competition under globalization. Even with the strong will and careful measures from the government, entrenched interests stemming from the socialist legacies exert stress on urban economic growth, impeding the economic efficiencies of urban resources, technologies and human capital. As a fusion of the government and the market, the process of SOE reforms will be long and painful. SOEs in industries such as aerospace and enterprises like Hafei Group, building upon their past achievements, still possess great value and potential. Instead of closing down, new life needs to be infused into these old factories with new technologies, personnel, management, and enterprise culture. All these are necessary to ensure successful economic transition.

\section{Acknowledgement}

The research is sponsored by a grant of the Natural Sciences Foundation of China (No. 41371008 and 41530751), the Early Career Talent Program of Chinese Academy of Sciences 'Youth Innovation Promotion Association of Chinese Academy of Sciences' (2014042), and China Scholarship Council (201504910654). The authors would also especially thank the Editor Prof. Andrew Kirby and two anonymous reviewers for their very insightful and constructive comments.

\section{References}

Biggs, J. (2015, Feb.). Uber opening robotics research facility in Pittsburgh to build selfdriving cars. TechCrunch.

Bombardier Aerospace (2015). Commercial aircraft status reports 2015. (In).

Carter, J. H. (2002). Creating a Chinese Harbin: Nationalism in an international city, 19161932. Ithaca, United States: Cornell University Press.

Chen, Y. (2014, August 21). China launches audit on RMB 15 trillion "land-transferring fee". China business news (in Chinese) (Shanghai).

China Business Times (2014, June 17). Small and medium enterprises have become a major tax source for Harbin. China business times (in Chinese).

Cho, M. Y. (2013). The specter of "the people": Urban poverty in Northeast China. Ithaca and London: Cornell University Press.

Edmonds, R. L. (1996). Søren Clausen and Stig Thøgersen: The making of a Chinese city: History and historiography in Harbin. (Studies in modern China.) xvi, 236 pp. London and Armonk, NY: M.E. Sharpe, 1995, \$22.50. Bulletin of the School of Oriental and African Studies, 59, 603-604.

Fan, G., \& Hope, N. C. (2013). The role of state-owned enterprises in the Chinese economy. China-US 2022.

Gamsa, M. (2010). Harbin in comparative perspective. Urban History, 37, 136-149.

Greenblat, A. (2014, Nov.). The progress and promise of Pittsburgh's turnaround. Governing.

Harbin Local Records Compilation Committee (1993). Harbin natural geography. Harbin: Harbin People's Press.

Harbin Municipal Government (2015). Harbin climatological summary 2015 [cited 11-25 2015]. Available from http://www.harbin.gov.cn/english/Harbin Overview/Climatological_Summary.htm (In)

Harbin Municipal Government Official Website. (Vol. 2016).

Harbin Statistical Bureau (2014a). Harbin social economic development report. Harbin Statistical Bureau.

Harbin Statistical Bureau (2014b). Harbin statistics yearbook. China Statistic Press.

Harris, S. H. (1994). Factories of death: Japanese biological warfare 1932-45 and the American cover-up. California State University. Northridge: Routledge.

Heilongjiang Airports Management Group (2015). Harbin airport introduction. Heilongjiang Airports Management Group Co., Ltd. 2015 ([cited 11-25 2015]. Available from http://www.haerbinairport.com.cn/airport/airportjieshao/).

Hurst, W. (2009). The Chinese worker after socialism. New York: Cambridge University Press.

Li, Q., Zhang, W., \& Wang, D. (2014). Current status, challenges and policy recommendations regarding the sustainable development of mining areas in China. Journal of Resources and Ecology, 5, 42-52.

Matsusaka, Y. T. (2003, September). The making of Japanese Manchuria, 1904-1932. In H. U. A. Center (Ed.), Harvard East Asian monographs (pp. 544).

Pei, P. \& Yang, F. (2008). Study on revitalizing Northeast China through a new road of industrialization/ETUDE DE LA REVITALISATION DU NORD-EST DE CHINE PAR UNE NOUVELLE VOIE D'INDUSTRIALISATION. Canadian Social Science, 4, 74.

Piiparinen, R., Russell, J., \& Post, C. (2015). From metal to minds: Economic restructuring in the Rust Belt. Urban publications, paper 1279. 
Rotstein, G. (2013, Oct.). 30 years of change: A new direction for Pittsburgh. Pittsburgh post-gazette.

Schilling, J., \& Logan, J. (2008). Greening the Rust Belt: A green infrastructure model for right sizing America's shrinking cities. Journal of the American Planning Association, $74,451-466$.

Solomon, L. (2013). Detroit: Three pathways to revitalization. New Brunswick, NJ: Transaction Publishers.

The Chinese Academy of Social Sciences (2008). The blue book of China's society, 2008. (In).

The Economist (2015, Jul. 11). Reinvention in the rust belt: America's industrial heartland. The economist.

Thrush, G. (2014, Feb.). The robots that saved Pittsburgh. Politico.

Tian, M. (2014, September 3). The role of land sales in local government financing in China. CKGSB knowledge.

Wang, X. (2011). Analysis on economic development and overindustrialization under the Manchurian regime. The Journal of Studies of China's Resistance War Against Japan (in Chinese), 5-12.
Wilson, D. (2007). City transformation and the global trope: Indianapolis and Cleveland. Globalizations, 4, 29-44.

Wilson, D., \& Wouters, J. (2003). Spatiality and growth discourse: The restructuring of America's rust belt cities. Journal of Urban Affairs, 25, 123-138.

Xu, C., \& Liu, Z. (2016). Research on challenges and policy recommendation for industrial transition in the northeastern region. Jianghuai Tribune (in Chinese), 1, 32-35.

Yang, D., \& Zhao, Z. (2015). Investment explanation of stagnation of economic growth in Northeast China. Northeast Asia Forum (in Chinese), 94-107.

Yang, Z., Cai, J., Ottens, H. F. L., \& Sliuzas, R. (2013). Beijing. Cities, 31, 491-506.

Yue, Y. (1993). Harbin local history. Heilongjiang People's Press.

Zhang, P. (2008). Revitalizing old industrial base of Northeast China: Process, policy and challenge. Chinese Geographical Science, 18, 109-118. 